\title{
Deteksi Arteri Karotis pada Citra Ultrasound B-Mode Berbasis Convolution Neural Network Single Shot Multibox Detector
}

\author{
Carotid Artery Detection in B-Mode Ultrasound Images Based on Convolution \\ Neural Network Single Shot Multibox Detector
}

\author{
I Made Gede Sunarya*1,5), Tita Karlita ${ }^{1)}$, Joko Priambodo ${ }^{1)}$, Rika Rokhana ${ }^{1)}$, Eko Mulyanto Yuniarno ${ }^{1,2)}$, Tri Arief \\ Sardjono ${ }^{1,3)}$, Ismoyo Sunu ${ }^{4)}$, I Ketut Eddy Purnama ${ }^{1,2)}$ \\ ${ }^{1)}$ Departemen Teknik Elektro, Fakultas Teknologi Elektro, Institut Teknologi Sepuluh Nopember \\ Jln. Teknik Mesin, Kampus ITS, Sukolilo, Surabaya, Jawa Timur, Indonesia 60111 \\ ${ }^{2)}$ Departemen Teknik Komputer, Fakultas Teknologi Elektro, Institut Teknologi Sepuluh Nopember \\ Jln. Teknik Mesin, Kampus ITS, Sukolilo, Surabaya, Jawa Timur, Indonesia 60111 \\ ${ }^{3)}$ Departemen Teknik Biomedik, Fakultas Teknologi Elektro, Institut Teknologi Sepuluh Nopember \\ Gedung B, C dan AJ Kampus ITS, Keputih, Sukolilo, Surabaya, Jawa Timur, Indonesia 60111 \\ ${ }^{4)}$ Departemen Kardiologi dan Kedokteran Vaskular, Universitas Indonesia \\ Jl. Letjen S. Parman, Kav.87, Slipi, Jakarta Barat, Indonesia \\ 5) Jurusan Pendidikan Teknik Informatika, Fakultas Teknik dan Kejuruan, Universitas Pendidikan Ganesha \\ Jalan Udayana 11, Kampus Tengah Undiksha, Singaraja, Indonesia 81116
}

Cara sitasi: I. M. G. Sunarya at al., "Deteksi Arteri Karotis pada Citra ultrasound B-Mode Berbasis Convolution Neural Network Single Shot Multibox Detector," Jurnal Teknologi dan Sistem Komputer, vol. 7 no. 2, 2019. doi: 10.14710/jtsiskom.7.1.2019.56-63, [Online].

\begin{abstract}
Detection of vascular areas (blood vessels) using B-Mode ultrasound images is needed for automatic applications such as registration and navigation in medical operations. This study developed the detection of the carotid artery area using Convolution Neural Network Single Shot Network Multibox Detector (SSD) to determine the bounding box ROI of the carotid artery area in B-mode ultrasound images. The data used are B-Mode ultrasound images on the neck that contain the carotid artery area (primary data). SSD method result is 95\% of accuracy which is higher than the Hough transformation method, Ellipse method, and Faster RCNN in detecting carotid artery area in the B-Mode ultrasound image. The use of image enhancement with Gaussian filter, histogram equalization, and Median filters in this method can increase detection accuracy. The best process time of the proposed method is 2.09 seconds so that it can be applied in a real-time system.
\end{abstract}

Keywords - object detection; carotid artery; ultrasound B-Mode; convolutional neural network; single shot multibox detector

Abstrak - Deteksi area vaskular (pembuluh darah) menggunakan citra ultrasound B-Mode diperlukan untuk aplikasi otomatis seperti registrasi dan navigasi dalam operasi medis. Penelitian ini melakukan kajian deteksi area arteri karotis menggunakan Convolution

*) Penulis korespondensi (I Made Gede Sunarya)

Email: sunarya@undiksha.ac.id
Neural Network Single Shot Multibox Detector (SSD) untuk menentukan RoI area arteri karotis dengan fitur bounding box pada citra ultrasound B-Mode. Data yang digunakan dalam penelitian adalah citra ultrasound B-Mode pada bagian leher yang mengandung area arteri karotis (data primer). Hasil metode SSD memiliki akurasi 95\% dan akurasi yang lebih tinggi dari metode transformasi Hough, metode Ellipse dan Faster RCNN dalam mendeteksi area arteri karotis pada citra ultrasound B-Mode. Penerapan image enhancement dengan filter Gaussian, histogram equalization dan filter Median memberikan pengaruh dalam peningkatan akurasi deteksi. Waktu proses terbaik dari metode yang diusulkan adalah 2,09 detik sehingga dapat diterapkan dalam sistem yang bersifat real-time.

Kata kunci - deteksi objek; arteri karotis; ultrasound B-Mode; convolutional neural network; single shot multibox detektor

\section{Pendahuluan}

Deteksi area vaskular (pembuluh darah) menggunakan citra ultrasound B-Mode diperlukan untuk aplikasi otomatis, seperti registrasi dan navigasi dalam operasi medis. Stroke adalah masalah kesehatan utama dan salah satu penyebab utama kematian dan kecacatan jangka panjang di seluruh dunia [1]. Beberapa penelitian telah menunjukkan bahwa pasien dengan plak aterosklerotik karotid membawa peningkatan risiko terjadinya masalah kardiovaskular, seperti stroke dan kematian [1], [2]. Stroke disebabkan oleh penyempitan 


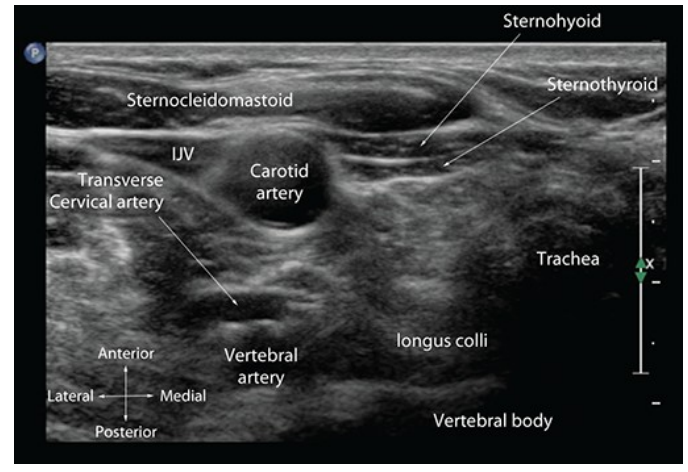

Gambar 1. Atlas ultrasound of Carotid Artery [21]

arteri karotis yang disebabkan oleh penumpukan plak. Penyempitan dalam arteri karotis meningkatkan peluang menderita stroke di masa yang akan datang [3].

Saat ini, deteksi dan kuantifikasi stenosis karotis biasanya dilakukan menggunakan modality MR atau CT angiografi yang membantu pembuatan keputusan dalam melakukan intervensi. Penentuan lokasi arteri karotis terutama difokuskan pada MR atau CT scan angiografi [4], [5]. Modaliti lainnya yang dapat digunakan untuk menentukan lokasi arteri karotis adalah ultrasonografi yang menghasilkan citra ultrasound B-Mode [6]-[10]. Penentuan lokasi arteri karotis menggunakan sebuah titik awal (seed point) sebagai titik inisialisasi [6].

Ultrasonografi ini telah banyak digunakan sebagai alat standar untuk diagnosis aterosklerosis arteri karotis [11]. Dibandingkan dengan modalitas pencitraan lain seperti MRI, CT dan PET, ultrasound menyediakan modalitas pencitraan yang lebih murah, lebih portabel, dan real-time untuk membantu mengukur dan memvisualisasikan arteri karotis. Ultrasound menyediakan cara non-invasif untuk memvisualisasikan berbagai jaringan dalam tubuh manusia. Namun, gambar ultrasound ini cenderung dipenuhi dengan speckle noise dan artifak lainnya. Penelitian dengan citra ultrasound B-Mode membutuhkan pemrosesan awal untuk meningkatkan kualitas citra (image enhancement), misalnya dengan filter Gaussian [12], [13] untuk mendapatkan citra yang lebih halus (blur), filter Median [12], [14], [15] untuk mengurangi noise berupa bintik kecil pada citra (salt and pepper), dan histogram equalization [15] untuk meningkatkan kontras dari citra. Kualitas gambar yang lebih baik di bagian Region of Interest (RoI) dapat membantu dalam proses penentuan area arteri karotis.

Penentuan lokasi yang tepat, segmentasi, dan pengukuran geometri arteri karotis menggunakan citra ultrasound B-Mode adalah penting dalam penilaian resiko stroke [6], [16]. Menandai lokasi arteri karotis secara manual membosankan, sangat subyektif, dan membutuhkan keahlian. Padahal, deteksi arteri karotis secara otomatis, deteksi, dan kuantifikasi plak dapat secara signifikan meningkatkan kecepatan dan akurasi diagnosis [17]. Secara visual bentuk arteri karotis terlihat seperti lingkaran ketika normal dan elips ketika ada penekanan oleh probe ultrasound. Deteksi untuk menentukan area arteri karotis menggunakan fitur lingkaran [18] dan fitur elips [12], [14], [19], [20]. Gambar 1 menunjukkan atlas citra ultrasound B-Mode pada area leher [21].

Kasus aterosklerosis karotis dapat ditangani dengan stenting arteri karotis. Stenting arteri karotis dapat dilakukan melalui femoral, brakialis/radial dan langsung melalui arteri karotis [22]. Penentuan titik awal dalam memasukkan jarum tidak dapat ditentukan dengan pasti dan juga posisi ujung jarum apakah sudah berada di dalam arteri atau tidak. Posisi arteri ada di dalam tubuh sehingga untuk saat ini dokter dalam menentukan titik awal memasukkan jarum dilakukan dengan memperkirakan dan tidak dapat ditentukan dengan pasti. Untuk dapat menentukannya, langkah pertama yang diperlukan adalah menentukan lokasi arteri karotis. Penentuan area arteri karotis harus dilakukan dengan cepat dan real time.

Saat ini, pemanfaatan metode deep learning convolutional neural network (CNN) telah digunakan peneliti dalam mendeteksi objek yang terdapat dalam citra. Salah satu arsitektur yang digunakan adalah CNN Single Shot Multi Detektor (SSD). SSD dengan Mobilenet menghasilkan waktu tercepat dibandingkan dengan Faster R-CNN dan R-FCN dengan akurasi 19,3 mAP dengan dataset COCO [23]. Selain fitur lingkaran dan elips, deteksi objek dalam citra dapat memberikan output berupa bounding box dengan aspek rasio dan skala yang berbeda untuk setiap lokasi feature map seperti dalam [24]. Objek yang digunakan adalah dataset VOC, COCO, ILSVRC. Hasil terbaik yang dicapai adalah $76.9 \%$ mAP pada Nvidia Titan X dengan ukuran input 512x512.

Dalam kajian ini, CNN digunakan untuk melakukan deteksi area arteri karotis. Arsitektur yang digunakan adalah Single Shot Multibox Detector yang digunakan dalam pelatihan dan penentuan RoI area arteri karotis pada citra ultrasound B-Mode dan membutuhkan waktu cepat [23]. Berbeda dengan [12], [14], [18]-[20], pelabelan RoI menggunakan fitur bounding box seperti [24] untuk menunjukkan area arteri karotis. Pemrosesan yang digunakan dalam kajian ini mempunyai urutan filter Gaussian, histogram equalization, dan filter Median untuk meningkatkan kualitas citra. Kinerja deteksi dengan CNN SSD ini, meliputi akurasi dan waktu proses, dibandingkan dengan transformasi Hough, deteksi dengan fitur ellipse, dan metode CNN arsitektur Fast RCNN.

\section{Metode Penelitian}

Penelitian ini meliputi beberapa proses training dan proses testing (Gambar 1). Tahapan training menghasilkan model yang sudah dilatih dan digunakan dalam tahapan testing. Tahapan training terdiri dari proses image enhancement dan menggunakan SSD. Tahapan testing terdiri dari proses image enhancement dan testing menggunakan model hasil tahapan training. Hasil dari tahapan testing adalah area pada citra yang mengandung arteri karotis. 


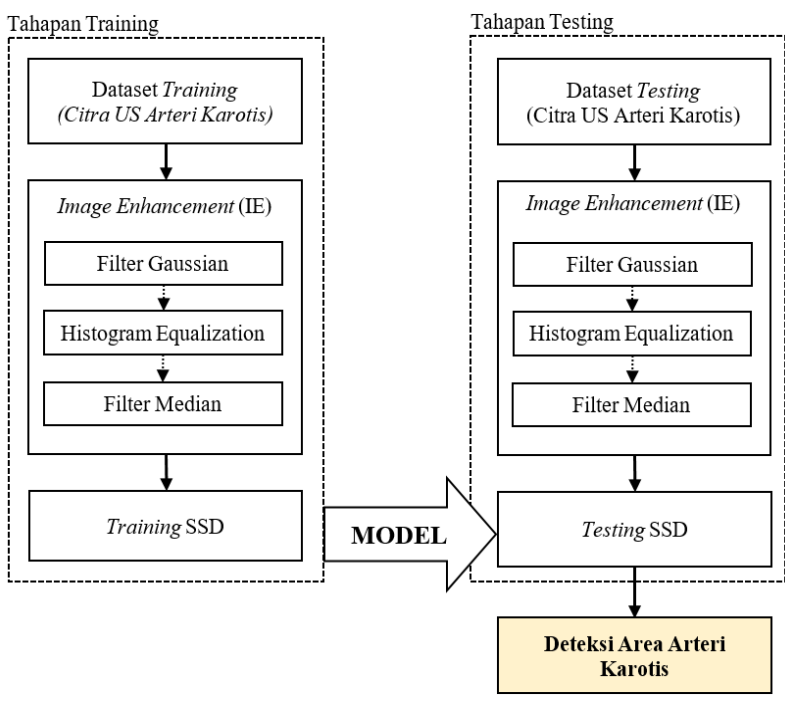

Gambar 2. Bagan metode penelitian

Pada penelitian ini, data yang digunakan adalah citra ultrasound B-Mode pada bagian leher yang mengandung area arteri karotis (carotid artery). Akuisisi data dilakukan secara langsung oleh peneliti (data primer) dengan menggunakan modaliti ultrasound SmartUs EXT-1M beamformer. Perangkat lunak yang digunakan adalah Echo Wave II. Tranducer yang digunakan adalah L15-7L40H-5 dengan frekuensi: 7-15 MHz. Pada akuisisi citra ultrasound B-Mode, parameter yang digunakan adalah frekuensi $=7.5 \mathrm{Mhz}$, variasi nilai parameter gain $=80 \%-95 \%$ dan depth $=30 \mathrm{~mm}$.

Data penelitian diakuisisi dari 5 orang yang berbeda. Jumlah citra yang digunakan sebagai dataset pelatihan (trainning) adalah 600 citra yang terdiri dari 20 dataset dan sebagai dataset uji (testing) sebanyak 450 citra. Dataset testing merupakan dataset yang mengandung citra yang tidak digunakan pada saat proses pelatihan. Deskripsi parameter akuisisi dataset yang digunakan pada penelitian ini ditunjukkan pada Tabel 1. Contoh citra yang digunakan pada penelitian ini ditunjukkan pada Gambar 3. Perangkat yang digunakan dalam penelitian ini adalah Laptop tipe Asus GL553VDFY330.

Proses image enhancement bertujuan untuk menyiapkan citra yang memperjelas area arteri karotis. Image enhancement diperlukan pada citra ultrasound BMode karena memiliki karakteristik yang kurang jelas secara visual dan banyak mengandung noise dan speckle. Tahap image enhancement yang digunakan dalam penelitian mempunyai urutan filter Gaussian, histogram equalization, dan filter median.

Training dan testing jaringan menggunakan arsitektur CNN SSD. Model ini dipilih karena membutuhkan proses yang bersifat real time. Pendekatan SSD berdasarkan pada feed-forward convolutional network yang menghasilkan bounding box berukuran tetap dan nilai skor untuk masing-masing kelas objek dalam area bounding box tersebut. Model arsitektur SSD ditunjukkan pada Gambar 4.
Tabel 1. Deskripsi parameter akuisisi dataset pelatihan

\begin{tabular}{ccccc}
\hline No. & Obyek & Frekuensi & Gain & Depth \\
\hline 1 & Obyek1 & $7.5 \mathrm{MHz}$ & $80 \%$ & $30 \mathrm{~mm}$ \\
2 & Obyek1 & $7.5 \mathrm{MHz}$ & $85 \%$ & $30 \mathrm{~mm}$ \\
3 & Obyek1 & $7.5 \mathrm{MHz}$ & $90 \%$ & $30 \mathrm{~mm}$ \\
4 & Obyek1 & $7.5 \mathrm{MHz}$ & $95 \%$ & $30 \mathrm{~mm}$ \\
5 & Obyek2 & $7.5 \mathrm{MHz}$ & $80 \%$ & $30 \mathrm{~mm}$ \\
6 & Obyek2 & $7.5 \mathrm{MHz}$ & $85 \%$ & $30 \mathrm{~mm}$ \\
7 & Obyek2 & $7.5 \mathrm{MHz}$ & $90 \%$ & $30 \mathrm{~mm}$ \\
8 & Obyek2 & $7.5 \mathrm{MHz}$ & $95 \%$ & $30 \mathrm{~mm}$ \\
9 & Obyek3 & $7.5 \mathrm{MHz}$ & $80 \%$ & $30 \mathrm{~mm}$ \\
10 & Obyek3 & $7.5 \mathrm{MHz}$ & $85 \%$ & $30 \mathrm{~mm}$ \\
11 & Obyek3 & $7.5 \mathrm{MHz}$ & $90 \%$ & $30 \mathrm{~mm}$ \\
12 & Obyek3 & $7.5 \mathrm{MHz}$ & $95 \%$ & $30 \mathrm{~mm}$ \\
13 & Obyek4 & $7.5 \mathrm{MHz}$ & $80 \%$ & $30 \mathrm{~mm}$ \\
14 & Obyek4 & $7.5 \mathrm{MHz}$ & $85 \%$ & $30 \mathrm{~mm}$ \\
15 & Obyek4 & $7.5 \mathrm{MHz}$ & $90 \%$ & $30 \mathrm{~mm}$ \\
16 & Obyek4 & $7.5 \mathrm{MHz}$ & $95 \%$ & $30 \mathrm{~mm}$ \\
17 & Obyek5 & $7.5 \mathrm{MHz}$ & $80 \%$ & $30 \mathrm{~mm}$ \\
18 & Obyek5 & $7.5 \mathrm{MHz}$ & $85 \%$ & $30 \mathrm{~mm}$ \\
19 & Obyek5 & $7.5 \mathrm{MHz}$ & $90 \%$ & $30 \mathrm{~mm}$ \\
20 & Obyek5 & $7.5 \mathrm{MHz}$ & $95 \%$ & $30 \mathrm{~mm}$ \\
\hline
\end{tabular}

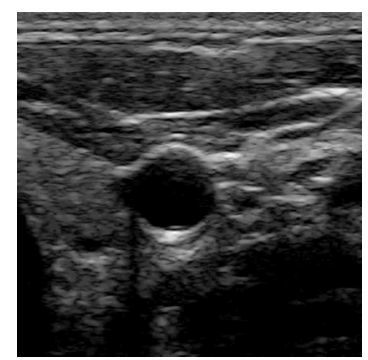

(a) Gain $80 \%$

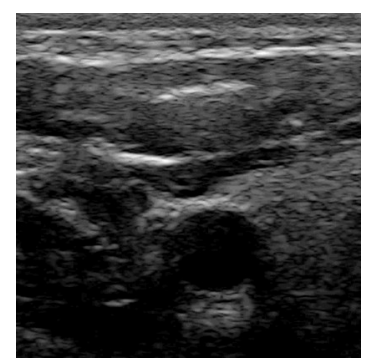

(c) Gain 90\%

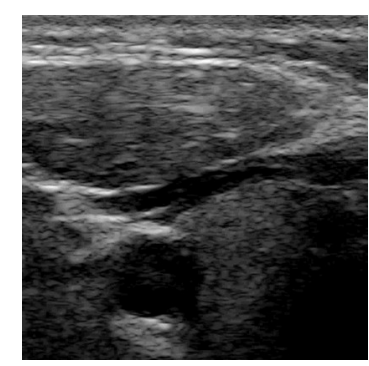

(b) Gain $85 \%$

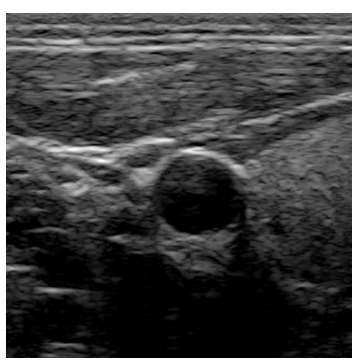

(d) Gain 95\%
Gambar 3. Citra ultrasound B-mode arteri karotis

Training dilakukan terhadap 20 dataset data pelatihan dengan menggunakan variasi jumlah epoch. Variasi jumlah epoch yang digunakan adalah sebesar $100,200,500,1000,1500$. Data pelatihan yang digunakan adalah data citra pelatihan tanpa image enhancement dan data citra pelatihan yang sudah diproses dengan image enhancement. Pada proses pelatihan akan dihitung nilai akurasi ketepatan deteksi pada urutan terbaik (Top 1) hasil deteksi arteri karotis.

Tahapan testing merupakan proses pengujian model hasil pelatihan. Proses pengujian menggunakan 450 citra yang tidak digunakan pada proses training. Proses 


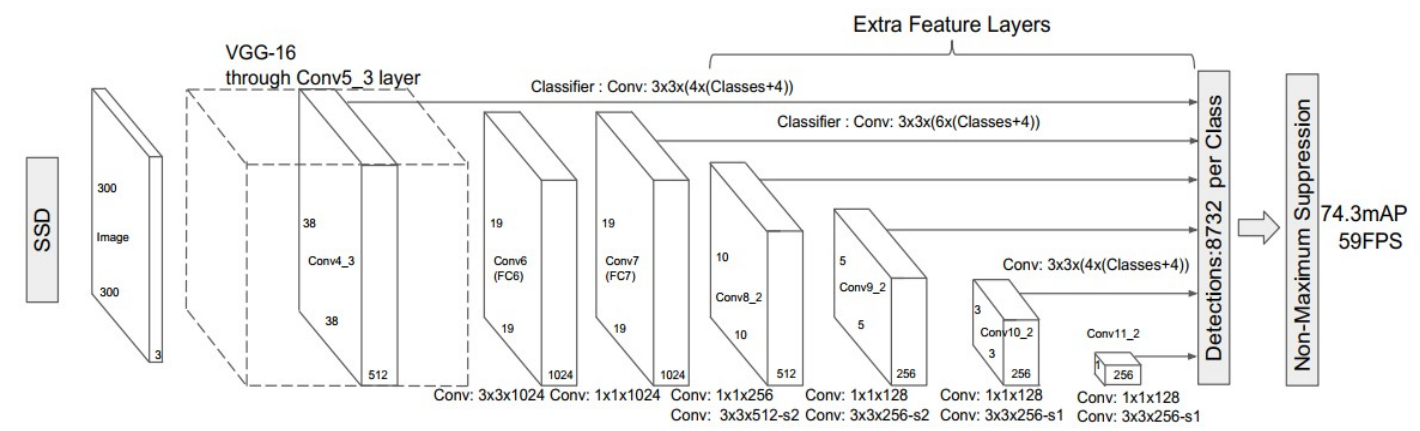

Gambar 4. Arsitektur model SSD

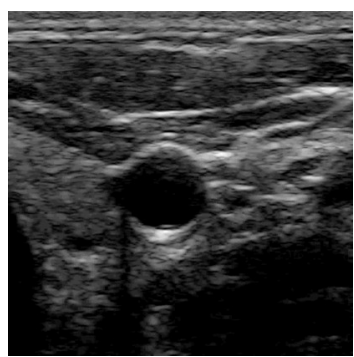

(a) Citra asli

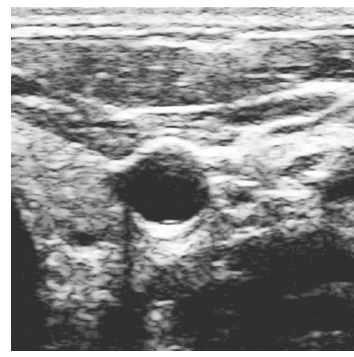

(c) Histogram equalization

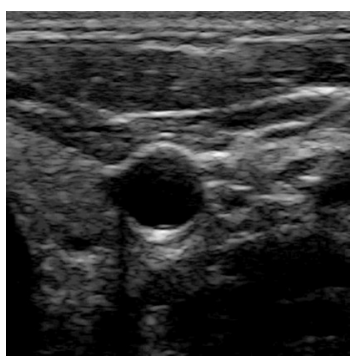

(b) Filter Gaussian

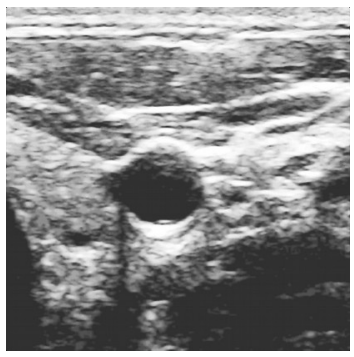

(d) filter Median

Gambar 5. Citra hasil image enhancement

pengujian dilakukan untuk memperoleh nilai akurasi dan waktu proses. Pada tahap ini dilakukan perbandingan dengan metode deteksi lingkaran transformasi Hough, deteksi dengan fitur ellipse, dan metode CNN arsitektur Fast RCNN.

\section{Hasil DAN PEMbahasan}

Data hasil akuisisi diproses dengan image enhancement (IE) menggunakan filter Gaussian, histogram equalization dan filter Median. Hasil pengolahan IE ditunjukkan pada Gambar 5. Hasil IE dengan filter Gaussian memperlihatkan citra yang lebih halus (blur) seperti [12], [13]. Hasil IE dengan histogram equalization menunjukkan peningkatan kontras dan peningkatan nilai di area batas arteri karotis sehingga batas tersebut semakin terlihat jelas seperti [15]. Hasil IE filter Median memperlihatkan hasil pengurangan noise yang berupa salt dan pepper seperti [12], [14], [15]. Dataset citra yang digunakan dalam pelatihan diberikan label yang menandakan area Region of Interest (RoI) arteri karotis.

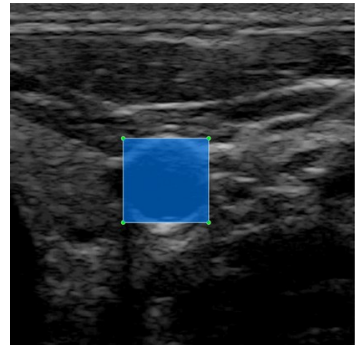

(a) Citra tanpa image enhancement

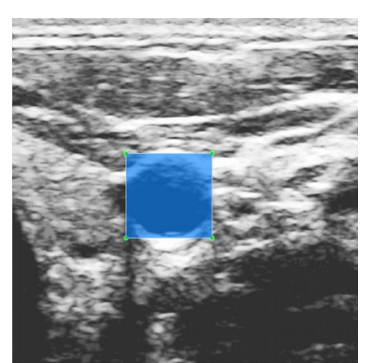

(b) Citra dengan image enhancement
Gambar 6. Citra hasil pelabelan RoI

Proses pelabelan RoI menggunakan aplikasi LabelImg. Pelabelan dilakukan pada dataset citra dengan IE dan tanpa IE. Gambar 6 menunjukkan hasil pelabelan pada dataset tersebut. Proses pelabelan juga menghasilkan file .xml yang memuat informasi dari path citra, ukuran, nama label, dan nilai batas-batas bounding box.

Pelatihan dataset training dilatih dengan menggunakan variasi dataset dengan IE, variasi dataset tanpa IE, dan variasi jumlah epoch. Parameter learning rate 0.004 dan batch size 24.Variasi epoch yang digunakan adalah sebesar 100, 200, 500, 1000, 1500. Hasil total loss function pelatihan dataset dengan IE ditunjukkan pada Gambar 7 dan data set tanpa IE ditunjukkan pada Gambar 8. Grafik total loss pada Gambar 7 dan Gambar 8 menunjukkan penurunan nilai loss yang berarti pelatihan berjalan baik dan mendekati nilai 0 . Hasil akurasi pelatihan dihitung dengan melihat keberhasilan pengenalan area arteri karotis pada posisi pertama (Top 1). Posisi pertama diperoleh ketika bounding box RoI dengan nilai tertinggi berada pada area arteri karotis. Hasil akuisisi area arteri karotis pada posisi Top 1 ditunjukkan pada Tabel 2. Hasil yang diperoleh menunjukkan bahwa pada pelatihan epoch 100, 500, 1000, dan 1500 akurasi dataset dengan IE memiliki nilai akurasi yang lebih tinggi dari dataset tanpa IE, sedangkan pada epoch 200 memberikan hasil yang sebaliknya. Nilai akurasi tertinggi pada dataset pelatihan dengan nilai epoch 1000 dan dataset dengan IE. IE seperti dalam [12]-[15] dapat meningkatkan akurasi deteksi arteri karotis. 
Tabel 2. Hasil akurasi Top 1 deteksi arteri karotis

\begin{tabular}{|c|c|c|c|c|c|c|c|c|c|c|}
\hline \multirow{2}{*}{$\begin{array}{c}\text { Data } \\
\text { set }\end{array}$} & \multicolumn{2}{|c|}{ Epoch 100} & \multicolumn{2}{|c|}{ Epoch 200} & \multicolumn{2}{|c|}{ Epoch 500} & \multicolumn{2}{|c|}{ Epoch 1000} & \multicolumn{2}{|c|}{ Epoch 1500} \\
\hline & DIE & TIE & DIE & TIE & DIE & TIE & DIE & TIE & DIE & TIE \\
\hline 1 & 30 & 23 & 27 & 25 & 28 & 22 & 14 & 21 & 3 & 20 \\
\hline 2 & 30 & 24 & 27 & 29 & 30 & 27 & 24 & 13 & 16 & 10 \\
\hline 3 & 11 & 10 & 26 & 26 & 29 & 20 & 16 & 27 & 30 & 29 \\
\hline 4 & 30 & 26 & 27 & 25 & 29 & 28 & 28 & 30 & 25 & 25 \\
\hline 5 & 28 & 23 & 22 & 30 & 29 & 29 & 30 & 27 & 30 & 30 \\
\hline 6 & 20 & 18 & 18 & 22 & 26 & 13 & 29 & 13 & 24 & 13 \\
\hline 7 & 21 & 9 & 5 & 23 & 6 & 9 & 27 & 21 & 25 & 18 \\
\hline 8 & 22 & 20 & 21 & 24 & 29 & 27 & 30 & 25 & 30 & 29 \\
\hline 9 & 30 & 30 & 30 & 30 & 30 & 30 & 30 & 30 & 30 & 30 \\
\hline 10 & 17 & 4 & 8 & 19 & 29 & 22 & 24 & 23 & 15 & 12 \\
\hline 11 & 30 & 30 & 30 & 30 & 30 & 20 & 30 & 9 & 30 & 25 \\
\hline 12 & 28 & 21 & 26 & 22 & 11 & 21 & 28 & 8 & 23 & 19 \\
\hline 13 & 30 & 30 & 30 & 30 & 30 & 30 & 30 & 30 & 30 & 30 \\
\hline 14 & 30 & 30 & 30 & 30 & 30 & 30 & 30 & 30 & 29 & 30 \\
\hline 15 & 30 & 30 & 30 & 30 & 30 & 30 & 30 & 30 & 30 & 30 \\
\hline 16 & 30 & 30 & 30 & 30 & 30 & 30 & 29 & 30 & 28 & 30 \\
\hline 17 & 18 & 4 & 5 & 16 & 8 & 19 & 7 & 11 & 6 & 14 \\
\hline 18 & 30 & 22 & 30 & 30 & 30 & 30 & 30 & 27 & 27 & 26 \\
\hline 19 & 29 & 21 & 27 & 18 & 30 & 23 & 30 & 16 & 24 & 1 \\
\hline 20 & 30 & 3 & 20 & 16 & 29 & 25 & 29 & 24 & 0 & 3 \\
\hline Jumlah & 524 & 408 & 469 & 505 & 523 & 485 & 525 & 445 & 455 & 424 \\
\hline Akurasi & 0.8733 & 0.6800 & 0.7817 & 0.8417 & 0.8717 & 0.8083 & 0.8750 & 0.7417 & 0.7583 & 0.7067 \\
\hline SD & 5.80 & 9.46 & 8.38 & 5.06 & 7.78 & 6.05 & 6.46 & 7.81 & 9.62 & 9.52 \\
\hline
\end{tabular}

$\mathrm{SD}=$ standar Deviasi DIE=Dengan Image enhancement TIE=Tanpa Image enhancement

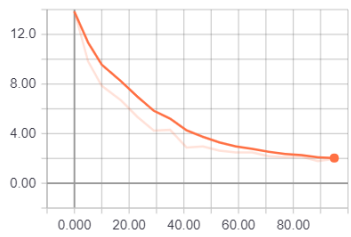

(a) Epoch 100

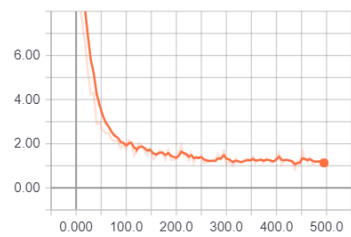

(c) Epoch 500

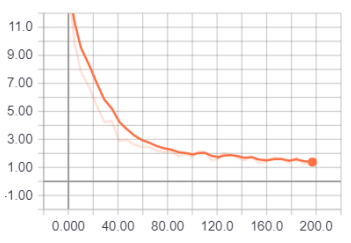

(b) Epoch 200

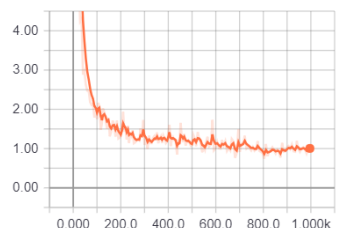

(d) Epoch 1000

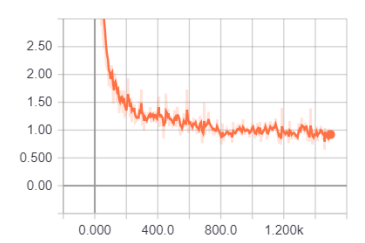

(e) Epoch 1500

Gambar 7. Grafik total loss pelatihan dataset image enhancement

Hasil deteksi berupa bounding box RoI pada citra dataset. Gambar 9 menunjukkan bounding box RoI berhasil mendeteksi arteri karotis pada posisi pertama, seperti halnya [24]. Pada citra IE dan tanpa IE yang benar terdeteksi menunjukkan hasil bounding box RoI berada pada area arteri karotis dan titik tengah dari

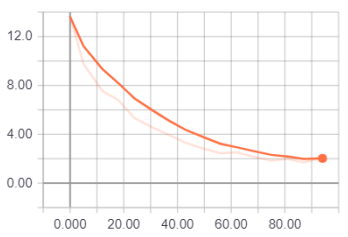

(a) Epoch 100

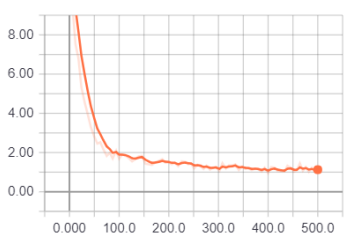

(c) Epoch 500

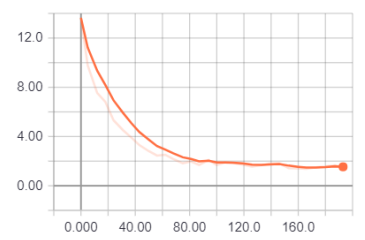

(b) Epoch 200

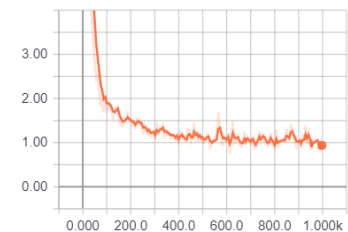

(d) Epoch 1000

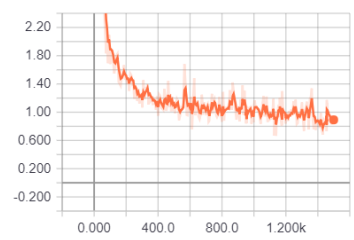

(e) Epoch 1500

Gambar 8. Grafik total loss pelatihan dataset tanpa image enhancement

bounding box berada di areah tengah (Lumen) arteri karotis. Pada citra dengan IE dan tanpa IE yang salah terdeteksi menunjukkan bahwa area yang terdeteksi tidak berada pada area arteri karotis. Pada bagian tersebut terlihat bagian yang menyerupai bagian dari arteri karotis sehingga memungkinkan memiliki nilai 


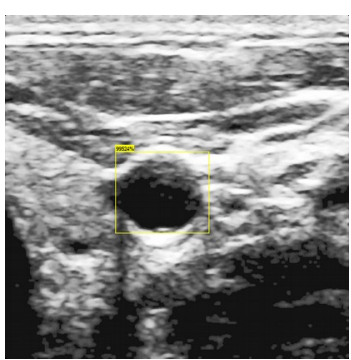

(a) Citra IE terdeteksi

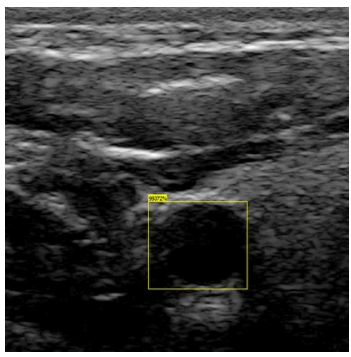

(c) Citra tanpa IE terdeteksi

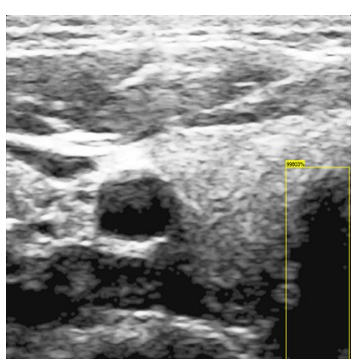

(b) Citra IE salah terdeteksi

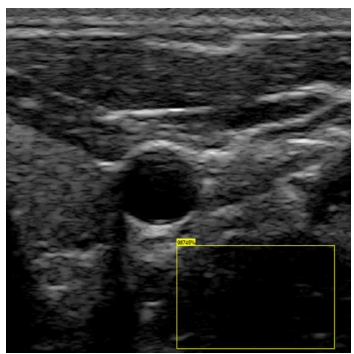

(d) Citra tanpa IE salah terdeteksi
Gambar 9. Hasil bounding box RoI dataset training

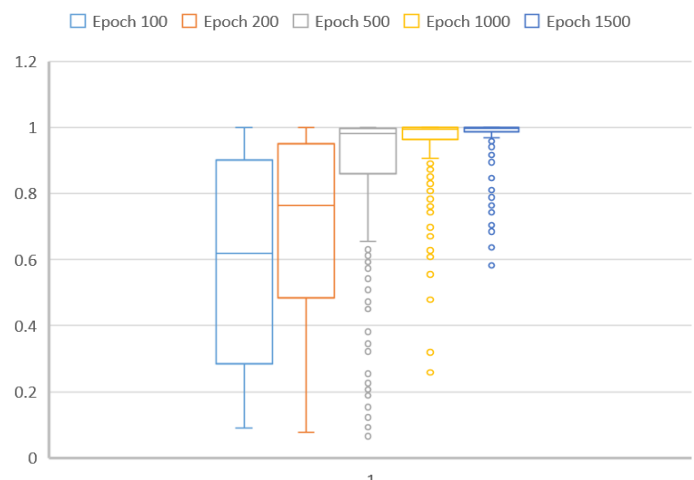

Gambar 10. Grafik akurasi hasil deteksi Top 1 pada dataset dengan IE

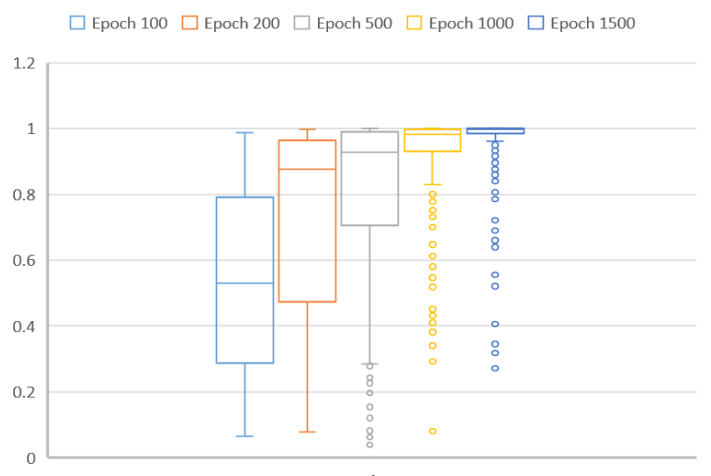

Gambar 11. Grafik akurasi hasil deteksi Top 1 pada dataset tanpa IE

akurasi yang lebih tinggi daripada pada bagian arteri karotis.
Tanpa IE

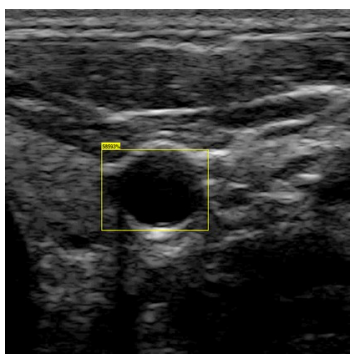

(a) SSD_Mobilenet
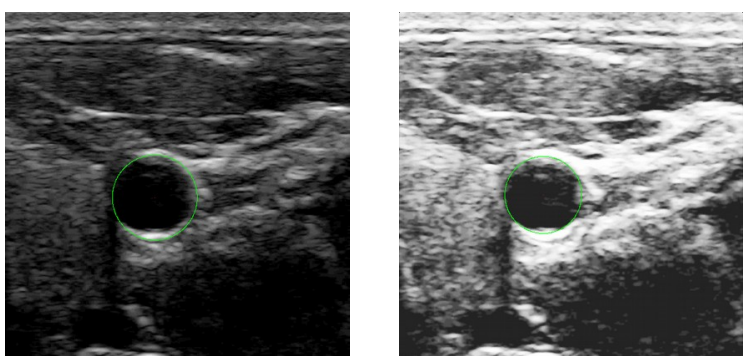

(b) Transformasi Hough
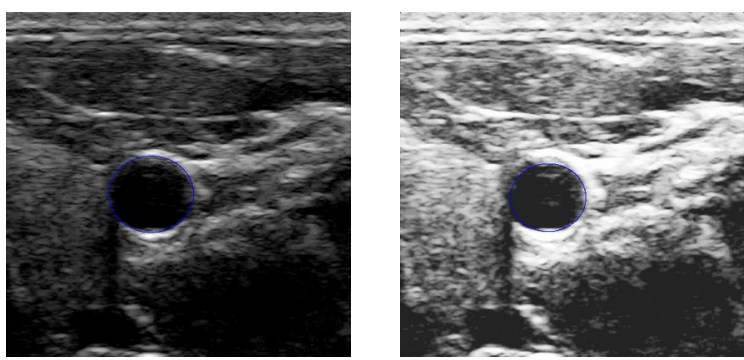

(c) Metode ellipse

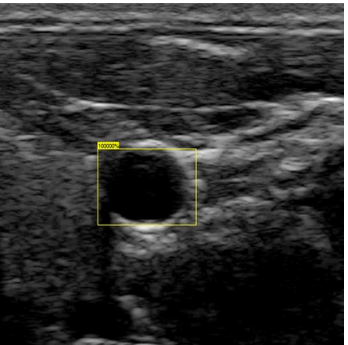

(d) Faster RCNN

Gambar 12. Citra hasil deteksi benar pada empat dataset tanpa IE dan dengan IE

Setiap citra memiliki nilai akurasi dengan rentang 01. Semakin tinggi nilai akurasi maka semakin tinggi keakuratan hasil deteksinya. Gambar 10 menunjukkan grafik akurasi hasil deteksi Top 1 pada dataset dengan IE dan Gambar 11 pada dataset tanpa memiliki rerata yang lebih tinggi daripada nilai rerata data set tanpa IE. Hasil ini sesuai dengan [12]-[15] yang menunjukkan IE dengan urutan filter Gaussian, histogram equalization, dan filter Median dapat meningkatkan akurasi deteksi.

Pengujian terhadap hasil model yang sudah dilatih menggunakan dataset pengujian. Dataset pengujian terdiri dari 450 citra yang tidak digunakan pada tahap pelatihan dan terbagi dari dataset dengan IE dan dataset tanpa IE. Dataset pengujian akurasi hasil deteksi yang diperoleh dibandingkan dengan metode pembanding 
Tabel 3. Akurasi dan waktu proses uji coba pada dataset uji coba

\begin{tabular}{lcccccccc}
\hline \multirow{2}{*}{\multicolumn{1}{c}{ Metode }} & \multicolumn{3}{c}{ Dataset Uji dengan IE } & \multicolumn{3}{c}{ Dataset Uji tanpa IE } \\
\cline { 2 - 9 } & \multicolumn{3}{c}{ Akurasi } & Waktu proses & \multicolumn{3}{c}{ Akurasi } & \multicolumn{3}{c}{ Waktu proses } \\
\cline { 2 - 9 } & Jumlah & Persentase & Rerata & SD & Jumlah & Persentase & Rerata & SD \\
\hline Transformasi Hough & 341 & 0.76 & 0.71 & 0.03 & 183 & 0.41 & 0.40 & 0.04 \\
Metode Ellipse & 333 & 0.74 & 13.23 & 1.39 & 226 & 0.50 & 11.78 & 0.21 \\
CNN_Fast_RCNN & 287 & 0.64 & 16.44 & 1.75 & 343 & 0.76 & 11.28 & 0.54 \\
CNN_SSD_Mobilenet_100 & 423 & 0.94 & 2.30 & 0.12 & 331 & 0.74 & 1.86 & 0.12 \\
CNN_SSD_Mobilenet_200 & 400 & 0.89 & 2.42 & 0.47 & 391 & 0.87 & 2.47 & 0.83 \\
CNN_SSD_Mobilenet_500 & 411 & 0.91 & 2.27 & 0.04 & 354 & 0.79 & 2.04 & 0.18 \\
CNN_SSD_Mobilenet_1000 & $\mathbf{4 2 7}$ & $\mathbf{0 . 9 5}$ & 2.21 & 0.15 & 323 & 0.72 & 2.10 & 0.11 \\
CN N_SSD_Mobilenet_1500 & 398 & 0.88 & 2.09 & 0.07 & 338 & 0.75 & 2.13 & 0.07 \\
\hline
\end{tabular}

$\mathrm{SD}=$ Standar Deviasi

lain. Gambar 12 menunjukkan citra hasil deteksi yang benar pada posisi arteri karotis. Gambar 12 pada baris 1-4 berturut-turut menunjukkan hasil deteksi dengan menggunakan metode SSD, transformasi Hough, metode elips dan CNN Faster RCNN. Kolom 1 menunjukkan hasil deteksi sesuai citra tanpa IE dan kolom 2 menunjukkan hasil deteksi sesuai citra IE.

Tingkat akurasi pada dataset pengujian dilakukan dengan menghitung jumlah persentase kebenaran deteksi pada urutan pertama (Top 1). Waktu proses yang diperlukan masing-masing metode dihitung dan dibandingkan. Tabel 3 menunjukkan hasil akurasi dan waktu proses uji coba pada dataset pengujian. Akurasi tertinggi dengan nilai persentasi 95\% dengan menggunakan metode SSD dengan epoch pelatihan 1000 dan dengan penerapan IE pada dataset pengujian, seperti yang diperoleh [23]. Persentase secara keseluruhan dengan menggunakan SSD memberikan hasil akurasi di atas $88 \%$. Penerapan IE pada dataset memberikan peningkatan akurasi untuk semua metode yang diujikan. Waktu proses antara dataset uji dengan IE dibandingkan dengan dataset uji tanpa IE menggunakan metode yang diusulkan memiliki selisih yang tidak tinggi yaitu paling tinggi sebesar 0,45 detik pada metode SSD dengan epoch 100. Waktu rata-rata proses metode yang diusulkan adalah 2,09 detik untuk akurasi $88 \%$ sehingga dapat diterapkan dalam sistem yang bersifat real-time, misalnya untuk penanganan stenting arteri karotis [22].

\section{KESIMPULAN}

Arteri karotis pada citra ultrasound B-mode dapat dideteksi berbasis convolutional neural network single shot multibox detector (CNN SSD) dengan akurasi 95\%. Penerapan IE dengan filter Gaussian, histogram equalization, dan filter Median dapat meningkatkan akurasi deteksi. Waktu proses dari metode yang diusulkan sebesar 2,09 detik memungkinkan untuk penerapan dalam sistem yang real-time.

\section{UCAPAN TERIMA KASIH}

Penulis mengucapkan terimakasih kepada Kementerian Riset dan Pendidikan Tinggi dan
Kementerian Keuangan Republik Indonesia, serta Lembaga Pengelola Dana Pendidikan (LPDP) Kementerian Keuangan yang telah membantu pendanaan melalui dana hibah beasiswa BUDI-DN.

\section{DAFTAR Pustaka}

[1] M. Naghavi et al., "From Vulnerable Plaque to Vulnerable Patient: A Call for New Definitions and Risk Assessment Strategies: Part I," Circulation, vol. 108, no. 15, pp. 1772-1778, 2003.

[2] L. G. Spagnoli et al., "Extracranial Thrombotically Active Carotid Plaque as a Risk Factor for Ischemic Stroke," JAMA, vol. 292, no. 15, pp. 1845-1852, 2004.

[3] A. J. Lusis, “Atherosclerosis,” Nature, vol. 407, no. 6801, pp. 233-241, 2000.

[4] R. Hameeteman et al., "Carotid Lumen Segmentation and Stenosis Grading Challenge,” in Proceedings of the Carotid Lumen Segmentation and Stenosis Grading Challenge, London, UK, Sept. 2009, pp. 1-16.

[5] H. Tang et al., "Semiautomatic Carotid Lumen Segmentation for Quantification of Lumen Geometry in Multispectral MRI,” Medical Image Analysis, vol. 16, no. 6, pp. 1202-1215, 2012.

[6] F. Mao, J. Gill, D. Downey, and A. Fenster, "Segmentation of Carotid Artery in Ultrasound Images: Method Development and Evaluation Technique," Medical Physics, vol. 27, no. 8, pp. 1961-1970, 2000.

[7] C. P. Loizou, C. S. Pattichis, A. N. Nicolaides, and M. Pantziaris, "Manual and Automated Media and Intima Thickness Measurements of the Common Carotid Artery,” IEEE Transactions on Ultrasonic Ferroelectrics, and Frequency Control, vol. 56, no. 5, pp. 983-994, 2009.

[8] F. Destrempes, J. Meunier, M. F. Giroux, G. Soulez, and G. Cloutier, "Segmentation in Ultrasonic B-Mode Images of Healthy Carotid Arteries Using Mixtures of Nakagami Distributions and Stochastic Optimization,” IEEE Transactions on Medical Imaging, vol. 28, no. 2, pp. 215-229, 2009. 
[9] S. Delsanto, F. Molinari, P. Giustetto, W. Liboni, S. Badalamenti, and J. S. Suri, "Characterization of a Completely User-Independent Algorithm for Carotid Artery Segmentation in 2-D Ultrasound Images," IEEE Transactions on Instrumentation and Measurement, vol. 56, no. 4, pp. 1265-1274, 2007.

[10] X. Yang, M. Ding, L. Lou, M. Yuchi, W. Qiu, and Y. Sun, "Common Carotid Artery Lumen Segmentation in B-mode Ultrasound Transverse View Images," International Journal of Image, Graphics and Signal Processing, vol. 3, no. 5, pp. 15, 2011.

[11] G. L. Kate et al., "Noninvasive Imaging of the Vulnerable Atherosclerotic Plaque," Current Problem in Cardiology, vol. 35, no. 11, pp. 556591, 2010.

[12] I. M. G. Sunarya, E. Y. Mulyanto, M. H. Purnomo, T. A. Sardjono, I. Sunu, and I. K. E. Purnama, "Carotid Artery B-Mode Ultrasound Image Segmentation based on Morphology , Geometry and Gradient Direction,” in Second International Workshop on Pattern Recognition, Singapore, Jun. 2017, pp. 5-9.

[13] D. D. B. Carvalho et al., "Lumen Segmentation and Motion Estimation in B-Mode and ContrastEnhanced Ultrasound Images of the Carotid Artery in Patients With Atherosclerotic Plaque," IEEE Transactions on Medical Imaging, vol. 34, no. 4, pp. 983-993, 2015.

[14] E. Yeom, K. H. Nam, C. Jin, D. G. Paeng, and S. J. Lee, “3D Reconstruction of a Carotid Bifurcation from 2D Transversal Ultrasound Images," Ultrasonics, vol. 54, no. 8, pp. 21842192, 2014.

[15] P. Poudel, C. Hansen, J. Sprung, and M. Friebe, "3D Segmentation of Thyroid Ultrasound Images using Active Contours," Current Directions in Biomedical Engineering, vol. 2, no. 1, pp. 3-4, 2016.
[16] D. Mozaffarian et al., “AHA Statistical Update Heart Disease and Stroke Statistics - 2015 Update A Report From the American Heart Association," Circulation, vol. 131, no. 4, pp. e29-e322, 2015.

[17] J. R. H. Kumar, “Automatic Detection of Common Carotid Artery in Transverse Mode Ultrasound Images,” in 2016 IEEE International Conference on Image Processing (ICIP), Phoenix, USA, 2016, pp. 389-393.

[18] S. Golemati, J. Stoitsis, E. G. Sifakis, T. Balkizas, and K. S. Nikita, "Using the Hough Transform to Segment Ultrasound Images of Longitudinal and Transverse Sections of the Carotid Artery," Ultrasound Medical Biology, vol. 33, no. 12, pp. 1918-1932, 2007.

[19] D. Gil, P. Radeva, and J. Saludes, "Segmentation of Artery Wall in Coronary Ivus Images: A Probabilistic Approach," Computers in Cardiology, vol. 27, pp. 352-355, 2000.

[20] J. Guerrero, S. E. Salcudean, J. A. McEwen, B. A. Masri, and S. Nicolaou, "Real-time Vessel Segmentation and Tracking for Ultrasound Imaging Applications," IEEE Transactions on Medical Imaging, vol. 26, no. 8, pp. 1079-1090, 2007.

[21] K. S. Manoj K. Karmakar, Edmund Soh, and V. Chee, Atlas of Sonoanatomy for Regional Anesthesia and Pain Medicine. McGraw-Hill Education, 2018.

[22] F. Aziz and A. J Comerota, "Carotid Artery Stenting Technique,” Medscape, 2018.

[23] J. Huang et al., "Speed/Accuracy Trade-Offs for Modern Convolutional Object Detectors,” in 2017 IEEE Conference on Computer Vision and Pattern Recognition (CVPR), Honolulu, USA, 2017, pp. 3296-3297.

[24] W. Liu et al., "SSD: Single Shot MultiBox Detector,” arXiv:1512.02325v5 [cs.CV], Dec. 2015. 